Linda M. LaPointe

\title{
Coffee anyone? \\ How marketing classes helped develop a business plan for a college library café
}

mages of a coffeehouse: poetry readings, political discussions, intellectual exchanges, quiet conversations, peaceful re ections, and good laughs. Where do these images of coffeehouses come from? Bookstore caf s, 60s coffeehouses lled with Beatniks, the Central Perk coffeehouse on the television show Friends, our family s kitchen table, or perhaps all of the above!

But would these coffeehouse images apply to a caf in a college library? Would a caf change students traditional images of the library as a solitary place? Would it foster intellectual conversations? Would someone dare a belly laugh? Would the ambience of a comfortable environment encourage learning on the conversational level? At Moravian College, we answered with the question, Why not?

\section{Invading the halls of silence}

Library literature in the late 20th and early 21st centuries refers to different models of functioning library caf $s$. These models vary from place to place but a central theme is one of recreating the image of the library from a solitary, quiet place to a more welcoming and appealing center. The concept of a relaxing area that permits and even encourages drinking, eating, and talking activities traditionally taboo in libraries is appealing to college and university administrators as well as librarians who aim to change the role of the library. After all, computers invaded the sacred halls of silence beginning in the late 1980s, why not coffee?

Reeves Library, the library of Moravian College and Moravian Theological Semi- nary, developed a unique way to establish a library caf . In 1992, the college expanded the library, thereby adding opportunities for use of new space. One of these spaces was in the lower-level periodicals area, complete with oor-to-ceiling windows and views of a lush green lawn. Initially hidden behind makeshift offices and periodical stacks, this area, once uncovered, seemed to be the perfect place to try something new a coffee shop.

As fellow coffeehouse innovators at Moravian and I now well know, the process of opening a library caf is daunting because most academic librarians are not trained in business models. Although academic librarians manage budgets, how would a staff of librarians translate their budgeting experience into a marketing plan, even if they had the time to develop one? If your library is lucky, like ours was, destiny steps in and a marketing professor walks through your door and proposes a wonderful solution: have his marketing classes develop a marketing/business plan as a service learning project.

\section{A class project}

During his orientation tour of the library, I met a new marketing professor, Gary Kaskowitz, and learned that he incorporates authentic assessment assignments and service

Linda M. LaPointe is technical services, serials and systems librarian at Moravian College and Moravian Theological Seminary, e-mail: lapointe@moravian. edu.

○ 2006 Linda M. LaPointe 


\section{The concept of a relaxing area that permits and even encourages drinking, eating, and talking- activities traditionally taboo in libraries-is appealing to college and university administrators as well as librarians who aim to change the role of the library. After all, computers invaded the sacred halls of silence beginning in the late 1980 s, why not coffee?}

learning projects into his classrooms. These types of assignments require students to develop marketing plans for real situations that exist within their communities.

As I described the vision of a library caf , bells within both of our heads started ringing and collectively we decided that Kaskowitz would design a class project in which students would develop a marketing plan for the library caf complete with targeted customers, cost projections, demographic statistics, and marketing strategies. After several brainstorming and organizational sessions with Kaskowitz, we decided to try to bring a real-life learning opportunity to his marketing students and provide the librarians with a plan to start a caf

Although our work did not follow the normal form of faculty librarian collaboration (the norm being the librarian teaching reference skills to a faculty member s research class), we embarked on a joint adventure.

Prior to collaborating with Kaskowitz, the librarians and I had developed several goals and taken some actions. Because the library wanted to reap the pro ts from coffee sales and use the monies on other projects, the library staff agreed to manage the caf . This was a key decision because although the college administration supported the caf in theory, they could not fund our caf .
Besides obtaining administrative approval, we also arranged an agreement with the college $s$ food service vendor (with exclusive rights to provide food on campus) over the opening of a caf beyond their scope. Further, we developed designs for the caf that would distinguish it from the rest of the library, which included comfortable furniture, tables, and Internet access for cyber-caf seating.

And nally, the library staff decided to uphold the ethics of fair trade by contracting only with coffee vendors who purchased directly from farmers and who paid the farmers a fair price for their product.

As a fall 2003 term project, the students enrolled in Kaskowitz s classes were assigned to create a marketing plan for the library coffee shop. As the library s liaison, I attended the classes and represented the library s goals, previous caf work, and interests. Following my presentations, the students asked clarifying questions. At the end of the class sessions, I provided the students with my contact information, and over time, my office was frequently visited by students with questions and plans.

Upon completion of the projects, the seven groups of student teams presented their caf marketing plans to me, their client, over four class sessions. After the formal presentations, I had the opportunity to question each group, thereby affording me an inside view to their business-oriented approach.

The enthusiasm surrounding the students and their presentations sticks out in my memory. For example, one group developed a promotional video and another group printed t-shirts with a caf name and logo for its presentation.

At the end of the semester, I received a printed copy of each plan. Through my exploration of the plans, I was able to incorporate many of their ideas into the library caf . The groups ideas ranged from the practical, such as purchasing and dis- 
playing student artwork in the caf, to the less practical for our speci c context, such as selling enough coffee to go national. In the end, one unexpected, but extremely important bene toccurred: we were selected as the recipients of the Senior Class Gift donation. Several of the marketing students were also members of student government and thanks to their efforts, the caf received its rst solid seed money from the seniors gift. With this pleasant surprise, we paid for plumbing for the coffee urns, electrical outlets, and caf furniture. The Senior Class donation, coupled with the enthusiasm of the marketing students, fed into the library staff $s$ belief that a caf $s$ time had come and that it would be well received by the students. In fact, student members of the Senior Class Gift Committee are using our caf as a model for their next project creating a comfortable meeting place in the student union.

\section{Has the café made a difference?}

One year later, our caf is a reality, serving as a caf open weekday mornings and evenings and also as an intellectually stimulating place to gather. We have a faithful and growing clientele of students, faculty, and staff. Friends of Reeves Library, a group comprised of interested alumni, faculty and staff, has taken interest in the project and generously supported the caf with several signi cant gifts. At the caf we buy coffee from a fair trade company, Green Mountain Coffee, which allows us to make an ethical statement simply through the coffee we serve.
We have also hosted several events, including faculty workshops on library resources, community-building gatherings for faculty and staff, art displays of student work that the caf purchased from the Senior Student Art Exhibit, reduced coffee prices, and extended hours during exam week, as well as theme parties, such as the Blue Book Blues Bash, which aimed to relieve nals week stress via a live jazz/blues band, a masseuse, and free food and coffee. And through it all we have maintained a healthy bank account. A contest held during the fall semester provided us with the nishing touch, a much needed name for the caf, AfterWords Caf .

But, has a library caf made a difference in the traditional image of the library as a solitary place? Was all the work, on the part of the librarians and Kaskowitz s students, worthwhile? In response to these questions, I think about a typical day in our caf in which a student and a faculty member converse over a cup of coffee or a student ts the nal piece into an impromptu, communal jigsaw puzzle or a group of students laugh over a political joke or a student sits crosslegged on an oversized couch and pours over the daily newspaper. In our opinion, all of our work was worth it because the milieu created by the caf has refuted the stereotype of the library as an unwelcoming place. In this broken stereotype s wake, we at Reeves Library instead witness a new image forming one of a library as a convivial place. Now that is an image that would make any librarian smile. $n$

\title{
Living the Future 6: WOW-Where Next?
} April $5-8,2006$ in Tucson, Arizona

\author{
Be a part of the dialogue: engage in the challenge \\ Early registration $\$ 350.00$ \\ www.library.arizona.edu/conferences/ltf/2006/ \\ co-bponsored by the: A6soclation of Feseanch Lbrarles, Assoclation of Colege and \\ Research Llorarles and the Unhersty or Arlzona Lbrarles
}

